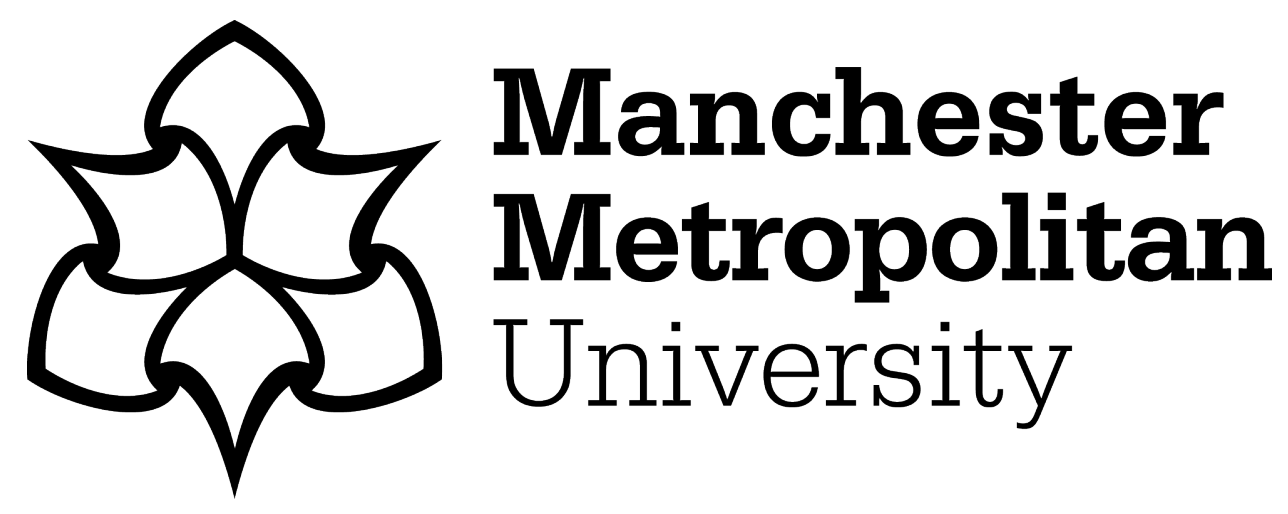

Wallace, Claire, Vincent, Kathryn, Luguzan, Cristian, Townsend, Leanne and Beel, David (2017) Information technology and social cohesion: A tale of two villages. Journal of Rural Studies, 54. pp. 426-434. ISSN 0743-0167

Downloaded from: https://e-space.mmu.ac.uk/622482/

Version: Accepted Version

Publisher: Elsevier

DOI: https://doi.org/10.1016/j.jrurstud.2016.06.005

Usage rights: Creative Commons: Attribution-Noncommercial-No Derivative Works 4.0

Please cite the published version 
Rural studies

Elsevier Editorial System(tm) for Journal of

Manuscript Draft

Manuscript Number: RURAL-D-14-00254R2

Title: Information technology and social cohesion: a tale of two villages

Article Type: Research Paper

Keywords: social capital, social cohesion, rural communities, quality of life, ICT, social and system integration

Corresponding Author: Prof. Claire Denise Wallace, PhD

Corresponding Author's Institution: University of Aberdeen

First Author: Claire Denise Wallace, PhD

Order of Authors: Claire Denise Wallace, PhD; Kathryn Vincent, PhD;

Cristian Luguzan, M.A.; Leanne Townsend, PhD; David Beel, PhD

Abstract: The study is about social cohesion in rural communities and how this interacts with Information and Communications Technology (ICT). Social cohesion is considered in terms of both system integration and social integration. System integration includes business and cultural organisations, civil society and communal spaces on and offline, which can provide bridging mechanisms to bring together disparate social groups. Social integration refers to more informal mechanisms of inclusion, including social networks, a sense of belonging, commitment to the common good. The paper considers these elements of social cohesion in relation to the intertwining of on and offline relationships by examining two contrasting rural communities in Northern Scotland. The paper concludes that ICT can play very different roles in social cohesion for different social and cultural groups as well as for different kinds of locational communities, but that ICT is becoming an integral part of rural social relations. 
Many thanks to the reviewers. I have incorporated their comments

Cover Letter

Many thanks to the reviewers. I have incorporated their comments

any thanks to the reviewers. I have incorporated their comments

Many thanks to the reviewers. I have incorporated their comments

any thanks to the reviewers. I have incorporated their comments

any thanks to the reviewers. I have incorporated their comments

any thanks to the reviewers. I have incorporated their comments

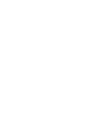

(1)

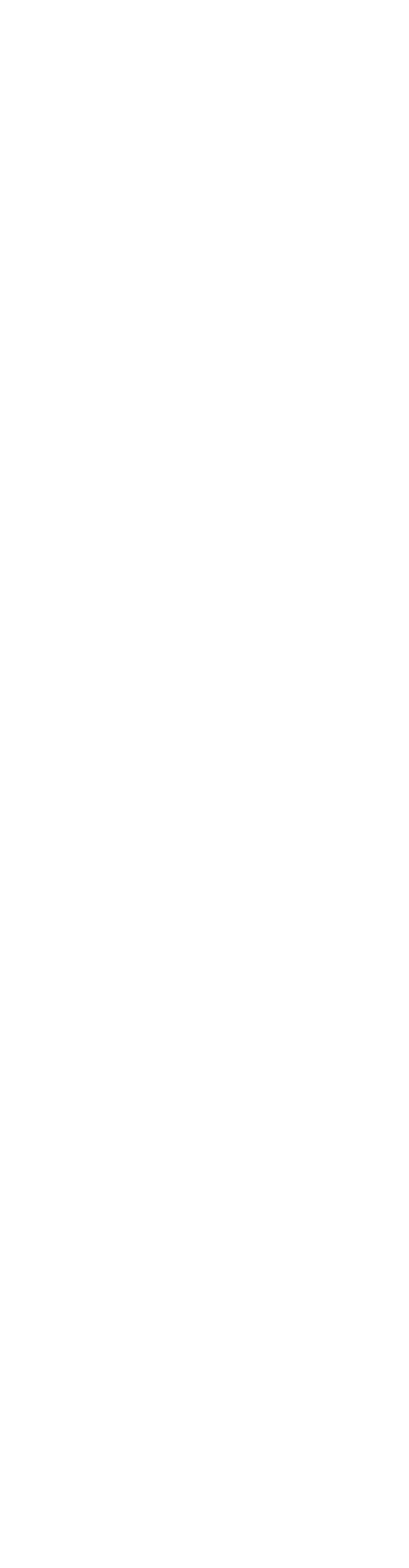


*Detailed Response to Reviewers

Many thanks to the reviewers. I have incorporated their comments 


\section{Information technology and social cohesion: a tale of two villages}

Claire Wallace, University of Aberdeen, School of Social Sciences, Aberdeen AB24 3QY

(corresponding author) Claire.wallace@abdn.ac.uk

Kathryn Vincent, University of Aberdeen University of Aberdeen, School of Social Sciences, Aberdeen AB24 3QY

Cristian Luguzan, University of Aberdeen University of Aberdeen, School of Social Sciences, Aberdeen AB24 3QY

Leanne Townsend, University of Aberdeen University of Aberdeen, School of Social Sciences, Aberdeen AB24 3QY

David Beel, University of Aberdeen University of Aberdeen, School of Social Sciences, Aberdeen AB24 3QY

Acknowledgements: This research was carried out through a grant from the EPSRC: Communities and Cultures Network+ EP/K003585 and forms part of the dot.rural Rural Digital Economy Research Hub EP/G066051 


\section{Information technology and social cohesion: a tale of two villages}

\section{Introduction}

The countryside is being transformed by the possibilities offered by Information and Communications Technology (ICT) to enable people to live and work remotely but also to interact with their local communities in new ways. For example, locational associations and informal groups such as football clubs, dancing clubs or book clubs can communicate their activities and Local Councils can provide a virtual information hub. ICT enables local communities to be created through online and offline interactions which have implications for the kinds of social cohesion that evolve. The paper considers how these local social relations are played out in new forms through digital interactions.

Social theorists have long pointed to the disappearance of traditional communities in the countryside and elsewhere through the disembedding of social relationships (Giddens, 1991) in favour of communities of choice and personal communities which are less likely to be locational (Pahl and Spencer, 2004).This disembedding of social relationships and traditional communities in time and space is further enabled through digital communications that can create new communities of interest and affect which are not localised at all (Rainie and Wellman, 2012) and are available $24 / 7$ at the click of a mouse or poke of a touch pad (Turkle, 2013). Hence, communities without propinquity take on new dimensions through ICT (Calhoun, 1998). However, people still live in local communities in which social relationships are meaningful and important and it is the re-embedding of these social relationships within a locality which are the focus of this study.

Digital communications also play an increasingly important part in this process as the community can be represented and "imagined" online in different ways. However, within communities various social layers interact with digital technology in different ways leading to different forms of social cohesion and different relationships to the community of place. Digital communications are usually seen as an integral part of the development of urban areas (see for example the recent digital cities catapult https://futurecities.catapult.org.uk/). Yet rural communities are interesting ones in this respect because their relative isolation and dispersion make ICT perhaps even more important (Townsend, et al., 2013). People might seek to make a living in the countryside, by setting up businesses or by commuting or remote working (Bosworth and Willett, 2011), but it is often quality of life that they are seeking, which can include quality of community life as they perceive it (Champion, 1989). They join people for whom the countryside is a source of more traditional forms of livelihood (such as farming or fishing) creating a series of socio-economic and cultural layers (Halfacree, 2008; OECD, 2008). The constant churn between in-coming and out-going populations in the last decades as young people move away to find work or education and older people move in to retire (Stockdale, et al., 2013) may make it difficult to easily distinguish between "incomers" and "locals" (Jedrej and Nuttall, 1996), although these distinctions might nevertheless hold a cultural or social salience. The tradition of community studies mainly focused on social relationships in more settled communities that were geographically bounded (Crow, 2002). However, new social relationships created by mobile residents and information communications suggest that many dimensions of community life, including social cohesion, need to be reconsidered. Nowadays, rural communities are ones of choice rather than necessity. But what sort of communities are they? 
The purpose of this paper is to look at how people create a sense of community and social cohesion in a local setting. It considers the role of ICT in enabling them to do so and how new kinds of community are thus created. ICT means that people do not need to leave their networks behind them when they move but there might nevertheless be re-embedding of social relationships at a local level. In doing so, people create their own sense of "elective belonging" (Savage, 2010) in their attachments to the places they have chosen to live and the social imagining of those places (Anderson, 1983). The richness of local social relationships, which we term social cohesion, are important for the "quality of life"(Phillips, 2006) to which social cohesion contributes (Abbott and Wallace, 2012).

\section{Theory: local communities and social cohesion}

Although social cohesion has a long history in social sciences, it has been more recently adapted to provide a framework for social policies at national and European levels (Ellison, 2012; Jones, 2013; Larsen, 2013) and is usually analysed at a national level, often in terms of quantitative indicators (Berger Schmitt, 2002). Deriving from Durkheimian sociology, social cohesion refers to the social bonds and social norms that hold society together (Durkheim, 1964) and has been recently operationalised through indicators to measure social networks, a sense of identity and the commitment to the common good (Dragolov, et al., 2013). So far, few people have tried to look at contemporary forms of social cohesion either qualitatively or at a local level and none have done so by considering ICT.

David Lockwood provides a framework for understanding social cohesion in terms of system integration:

"Whereas the problem of social integration focuses attention upon the orderly or conflictful relationships between actors, the problem of system integration focuses on the orderly or conflictful relationships between the parts of a social system." (Lockwood, 1992: 400)

In other words, system integration can be seen to relate to the community as a whole and the relationships of the different parts within it, whilst social integration refers to the way in which individuals are linked to the community through social inclusion (Abbott, et al., 2016).

But how can it be operationalised empirically at a local level? Here we consider system integration as the relationship between different structural elements of the local social system - how cleavages of social classes, age, divisions between what are perceived as "incomers" and "locals" are bridged. We consider social integration as the way in which individuals are connected to the local community through social networks, social capital, a sense of belonging and working for the common good.

Beginning with system integration, social cleavages can be particularly acute in small communities where people live in close proximity, but are themselves dynamically changing. They can also be lived out in virtual communities as different social groups use ICT and interact with their communities in different ways. Cleavages according to income as well as culture might be found but also according to age as the divide emerges between those who use a variety of communications media and those who use only limited media or none at all (although the latter group are rapidly disappearing) (Dutton and Blank, 2012). Here we can identify offline sites of interaction in the form of meeting places such as greens and streets for casual interaction, commercially provided community hubs such as pubs, shops and cafes or collectively organised spaces such as meeting 
halls, notice boards and museums. The density and nature of civil society organisations such as youth clubs, local history associations and religious organisations can be greatly augmented through online communications on which they increasingly depend (Huysman and Wulf, 2004; Wallace, 2013). Online meeting spaces encouraging system integration can also be websites which provide collective resources and information. However, many of these sites are provided officially through local authorities and it is not clear how much community activities really form part of this virtual space or how much local residents are able to engage with it. Locally produced radio and TV stations, as well as paper or online newsletters, help to bridge this divide between official communications and citizen participation. In rural areas, the local Community or Parish Council can help to make these collective spaces into ones that engage residents but their degree of activity and representativeness of local interests is variable.

Turning now to social integration, this refers to the way in which people are connected into the community at an individual or group level and can be explored both online and offline. An important element of this is social networks binding people to a community and thereby generating social capital (social capital being seen as the added social value produced by networking). This includes "bridging social capital" that can link to others outside personal networks (Lin, 2001; Putnam, 2000) and "bonding social capital" that can help to reinforce more affective social relationships. Both forms of social capital are important for generating social cohesion. Social capital can potentially be augmented by ICT communications, including the weak ties that enable people to " get things done" (Granovetter, 1974) as well as the strong ties reinforced by social media such as Facebook, WhatsApp and texting. The synthesis of bridging and bonding social capital assisted can be even more strongly reinforced in rural areas on account of the overlapping of multiple social ties (Townsend, et al., 2015 ).

A second element of social integration is the feeling of belonging to the community (Dragolov, et al., 2013). This sense of belonging, identified at a national level as a powerful emotional commitment to a territory and its related community (Guibernau, 2013), could also be found at the local level in some communities that generate local loyalties and elective affinities. In some cases it can be the effect of the physical landscape that has emotional implications (Ingold, 2000), but social solidarities are cemented by a sense of loyalty and commitment to the group, which some contexts foster more than others (Crow, 2002). This sense of identification can be explored through subjective perceptions of individuals but also through the multiple ways that the evocation of the locality is an explicit focus of online communications.

A third element of social integration as a factor in social cohesion is a commitment to the community and the "common good" for which people might be prepared to invest time, capital or other resources (Dragolov, et al., 2013). Commitment to the community as a common good is based on altruistic notions of the worthiness of local causes and putting collective interests above individual ones - although these activities can also be vehicles for furthering individual self-interest as Lin demonstrates (Crow, 2002; Dragolov, et al., 2013; Lin, et al., 2001). For Putnam it is this collective good that is fostered through social capital to foster "civic mindedness" which is also the basis for prosperity and democracy (Putnam, 2000). In his studies, it is this civic mindedness which distinguishes the prosperous North of Italy from the "backward" South (Putnam, et al., 1993). Social capital is therefore generated through activities like volunteering, working for community-oriented goals as well as the nature and extent of local social enterprise. Although Putnam does not mention 
social enterprise, these kinds of projects which draw on local social activism and generate social and economic capital for the community can be seen as important elements of local social cohesion. Many studies have argued that participation in local civil society activity is also enhanced by digital communications (Pigg and Crank, 2005)

All of these elements of social cohesion illustrate the intertwining of online and offline social relationships in everyday life. The kind of online presence and activities that it suggests may give an idea about the nature of social cohesion in a particular locality. In this respect online research can greatly augment the more traditional social science methods such as ethnography and interviews, as we shall show.

\section{Methods}

Two communities in Scotland were selected for study: one a relatively remote rural community set at the end of a peninsula with a strong tradition of community engagement and the second a village within easy commuting distance of a major urban settlement. The two villages, which we will term "Peninsula Village" and "Commuter Village" are of comparable size with around one thousand inhabitants. The first community had enjoyed online communications for some twenty years, being one of the first localities in Scotland to be linked to Internet and later to high speed broadband through a fibre optic cable set up by a local private company. The second community initiated their own fast broadband access through a social enterprise only two years prior to the study taking place, although they were previous connected through slower landline telecommunications infrastructure more common in rural areas. The two communities represent contrasting experiences of rural living in contemporary Britain.

Fieldwork and interviews were carried out between 2012 and 2014 by three members of the team. The methods employed took two main forms: interviews and participant observation in the communities and analysis of public online communications associated with each place. The former involved interviews with key informants in both communities including the social entrepreneurs who set up the broadband networks, youth leaders, local councillors, local businesses and civil society participants in clubs and organisations. These helped us to identify different community fractions and so we endeavoured to interview representatives from them: younger and older people; people from different social class communities; recent arrivals and more long established residents. These community fractions represented cultural configurations recognised in the communities themselves - so for example the cultural distinction between "incomers" and "long term residents" was one such distinction even if it did not entirely map onto length of residence and in practice even long term residents tended to come, go and return. Cultural differentiations were likewise reflected in local assessments such as between one end of the village and another or between membership of different clubs and associations, or frequenting of different social hubs. The reproduction and salience of these kinds of cultural differentiation reflect important and meaningful divisions for people with different forms of habitus (Bourdieu, 1984; Savage, 2010). Some of these were digitally active, some less so and some not at all. Around twenty respondents from different socio-cultural groups were interviewed in each locality over a period of months. Participant observation was carried out in community hubs such as restaurants, shops, cafes, festivals and pubs. 
In addition an analysis of websites and online participation was carried out by comparing online presence during the same period (carried out during August 2013). The web analysis took three forms. First, the community websites were accessed and analysed in terms of their content based on the approach to social cohesion discussed above. Second, a Google search for sites related to the name of each locality was carried out to understand the extent to which the locality itself was a market for online communications. Thirdly, social media was analysed by searching for Facebook sites associated with the name of each location. Together these methods aimed to capture online presence although they could not be exhaustive since they covered only public sites where the name of the place was included.

Interviews were transcribed and analysed using the Framework method of qualitative analysis and to this was added the classification of online activities (Spencer and Ritchie, 1994). This combination of resources provided a cascading framework of analytical categories for system integration (relationships between different groups, common sites of interaction) and social integration (social networks, a sense of belonging and commitment to the common good) that enabled us to merge the different online and offline methodologies.

Since many rural communities lack good broadband connections, and are indeed falling further and further behind their urban counterparts (Townsend, et al., 2013) we have focused upon villages that had fast broadband connections. They are therefore not necessarily typical of other rural areas but fitted the purpose of our study.

\section{Two Villages with ICT}

Official statistics provided by the Scottish Government using Scottish Indicators of Multiple Deprivation that can be broken down to postcode level, indicate that both communities are relatively affluent communities with low levels of deprivation on average (http://www.sns.gov.uk/). House prices were high, reflecting the fact that they are both desirable places to live and Peninsula Village had a slightly older population than Commuter Village. Commuter Village has a higher proportion of families with young children than the national average. Social problems related to drugs and crime were low in both villages although both contained pockets of deprivation with 10 per cent being income deprived in Peninsula Village and 5 per cent in Commuter Village. Furthermore, there are high levels of social housing in Peninsula Village, which were concentrated into one end of the village, creating a geographical as well as a social divide.

Peninsula Village had been a rundown fishing village since the nineteenth century, but was gentrified with housing improvement grants from the 1980s onwards with an influx of "bohemian" middle class bringing high levels of cultural capital even if they did not necessarily have high incomes (Florida, 2002). Although Florida (2002) has looked at how this can help to transform urban neighbourhoods into desirable and trendy places through the intensity of cultural activity that these groups bring with them, it would seem that this is also applicable to some rural areas as well. The creation of good Internet access since the 1990s and later high speed broadband was one of the initiatives of these incoming entrepreneurs, since creative industries depend increasingly upon digital media (Townsend, et al., 2015), but it opened the way for other digital and creative enterprises to locate there. It is now a tourist destination with heritage attractions located 23 miles from the nearest large town at the tip of a peninsula. 
Commuter Village was largely a farming community until the advent of the oil industry in Aberdeen brought in wealthy middle class home owners, often living in large, new, detached houses or in recently renovated accommodation. The influx of a mobile community, often with technological expertise on account of their professions and demanding high levels of connectivity to pursue their work and their social interests prompted the move to create a fast broadband connection through the initiative of local people. However, Commuter Village is characterised more by technological than cultural capital as it did not enjoy the high level of cultural life in terms of festivals, events and arts and crafts activities (Bourdieu, 1983).

Both villages reflected an influx of the incomers with different perspectives and aspirations over a period of decades and they are examples of different kinds of rural living in contemporary Britain. The villages were selected primarily on account of the availability of fast broadband connections since this was an integral part of the study we carried out.

\section{System integration : bridging social cleavages}

Social cohesion at the systemic level involves the integration of different social cleavages through civil society and common sites for interaction both on and offline. Calhoun (1998) mentions this in terms of abstract, bureaucratic social relationships, but we can also apply this in ways that more relevant for local social interactions. In Peninsula Village there were many opportunities for making these connections. There were many communal points of interaction. The Post Office, the supermarket, the community bakery and the "Emporium" selling souvenirs, books (both new and second hand), and postcards as well as craft work operated as community hubs with a variety of notices in the windows. Notwithstanding the rather isolated location of the community, there were many festivals and events that attracted people from outside. A local hotel and two thriving pubs attract different groups of regular and occasional customers. A local restaurant which began as a social enterprise, acts as a meeting point for different elements of the community including young and old and helps to host community events. Two local Universities have restored buildings within the town and stage events there. The traditional architecture of this former fishing village with densely packed houses, often in terraces fronting onto the streets and alleyways, encourages casual encounters with neighbours. Many of the civil society activities were organised through the Community Arts Trust which organised regular events. There were clubs targeted at older residents and a youth café, partially funded through a legacy left to the town.

There were nevertheless social cleavages in Peninsula Village based upon age and social class. In terms of age, the young people tend to move away from the village in order to go to University, to seek work or more exciting lifestyles, leaving behind an ageing population. However, on account of the sense of security, trust and community spirit (which was acknowledged by everyone we spoke to) people with young children tended to move to the village, including returnees. The different generations of young people all attended the local school and some of them formed age cohorts who stay in touch through Facebook even when they have left the area, although these were generally divided between those who went to University and those with lower educational qualifications dependent upon more local opportunities. The age-specific cohorts sometimes give themselves distinctive identifying monikers (such as "Peninsulans On Tour" ). Young people were more likely to communicate using smart phones, texting and YouTube, whilst the older people used email. Despite the excellent broadband coverage, young people complained about the poor $3 \mathrm{G}$ 
coverage, which prevented them from using their mobile devices as much as they would have liked (4G was not even mentioned at the time of interviewing). Young people used ICT communications (mainly on their mobile devices) to organise social life, such as parties or meetings and to keep up to date with friends. Communication was continual and one young person talked of texting 2-3 times an hour with her friends and having at least daily Facebook contact. The young people from the youth club had posted a video of themselves on YouTube which had enjoyed 15,000 hits. Even those from the more socially deprived end of town had play stations, Xboxes and mobile devices.

Peninsula village had a well-developed website set up and maintained by the Community Council and reflecting the long period of development of the community since the 1980s. A count of associations mentioned in the website of Peninsula Village included religious worship, a bowling club, Ceilidh Dances, Art Exhibitions (several of them), Craft Fairs, musical weekends and musical events (mostly folk music which has a strong following in Scotland), a Boating Club, Football Club, Tennis Club, Lifeboat Club, Mothers and Toddlers club, Snooker Club, an Allotments and Gardens Society and a Friends of the Church Society. There was a calendar where almost every day was filled with activities and events. Altogether 16 local businesses were listed on the website and there was a special section for Artists and Crafts businesses of which there were also 16. Businesses included a local Brewery, an Antiques Shop and a Cheese Shop selling specialist cheeses and itself a venue for various community events. Under health and fitness were listed salsa dancing, reiki massage, crystal healing and a variety of alternative therapies. It is perhaps the "creative class" (Florida, 2002) that has helped to transform social and cultural relations in this region and attract like-minded people. In fact the community website worked as a form of system integration to bring together all these diverse interests within the local community including different social and age groups, new arrivals and older residents

A search using the village's name on Facebook revealed 87 Facebook groups in the area. However, 60 of those were automatically created by Wikipedia due to users expressing an interest. These auto-pages were most often about local landmarks, nearby towns or historical figures, but the only postings tended to be the description generated by Wikipedia and there were few, if any "likes" among them. Of the remaining 27, the majority (11) were for local businesses, many of them designed to attract tourists. There were also pages for businesses, including the brewery, and two Facebook pages for one of the two pubs. As well as a page for the main hotel, there are four pages for holiday cottages and for the local caravan sites. Three of the businesses were entertainment/activity based, including a music venue, dolphin tours and a ferry for sightseeing. In addition, there were eight pages for community groups, a mixture of sports clubs and cultural or arts organisations and NGOs -including the film society, the Community Arts Trust, the Citizens' Advice Bureau and the cycling club, amongst others. There were five pages about events, including the New Year's ocean dip, a film festival, and community markets

We also carried out a Google search for the most prominent local websites in each of the villages. When putting the name of the Peninsula village into Google, we analysed the first ten pages of results, with the exception of those websites which only had one page dedicated to the village ${ }^{1}$. In this way, we were able to examine 45 websites. Seventeen of the websites were for local businesses. As with the Facebook sites, the businesses tended to be related to the tourist industry. There are two websites for local hotel/bed and breakfasts, as well as four sites for holiday cottage rentals. There are four websites for retail shops, including the post office, the local gift shop, a 
pottery gallery and a cheese store. In addition to the brewery and pub which we found on Facebook, there was also a site for the local café and three businesses associated with the harbour, including the aforementioned dolphin tours and ferry. Finally there is a company which hires out archaeological services in the area.

Twenty six websites, including the official site, were classified as community based. Ten of these groups were for activities, including the boat club, sports council, allotments, the film society and camera club. There were eight websites which related to historical or cultural societies, including building preservation societies. The final eight are a combination of local government, religious and Masonic groups. Finally, there were two websites about annual events - a film festival and a New Year dip in the sea.

The community website in Peninsula Village was itself a source of system integration as it brought together the activities of different groups. It was set up and controlled by the Community Council but with very active participation of the community itself, but was edited and orchestrated by this organisation as an outward and inward facing projection of the community. Social Media was much wilder and less controlled and in this respect, so online presence could also undermine social cohesion. Youth workers and community workers were in fact wary of using Facebook as they claimed that this made young people prey to those who would use this communication media exploitatively and also because gossip tended to inflate into "flaming" online dramas which blew up problems and difficulties rather than resolving them.

Despite the social class divisions and those between incomers and natives, everyone in Peninsula Village commented on the strong sense of community that was to a great extent able to overcome these divisions:

It's a great community, Peninsula Village, it is a fantastic community. I mean it's quite rare as a community. It's quite unique in lots of ways. ...We have a strong community spirit here. (Female PV)

Whilst in Peninsula Village a number of social enterprises had been initiated and levels of volunteering were high, in Commuter Village, the main social entrepreneur had difficulty in enlisting the help of others within the community to set up the Community Broadband (even though in the end it would benefit everyone). He was treated with suspicion by others who wanted financial compensation for using their properties to relay the signal around the area. One farmer refused to co-operate, yet another saw the benefits for his business and co-operated enthusiastically. Another householder objected to a telegraph pole being erected in front of his house. The lack of engagement by a wider group of people has hindered the sustainability of the broadband initiative.

The rather expensive nature of the broadband network that had been set up in Commuter Village (£100 per month for the "gold" service, but cheaper for lesser services) meant that this service was more available to the wealthier members of the community and poorer people (even teachers), were not able to subscribe to the gold service. Even the lower level of services at $f 50$ per month is more than would be charged by many conventional broadband providers.

In Commuter Village the public online presence was very limited. The website contained information about the broadband project and what to do in case of problems, as well as information 
about a heating oil club enabling villagers to get cheaper fuel. The only other listing was about the local school. The Commuter Village broadband was set up through a social enterprise enlisting the support of other householders in the neighbourhood. The resulting superfast broadband connections were mainly used by householders to stream TV or movies and to communicate to relatives through video conferencing connections (people working in the oil industry are often working for periods of time abroad). Whilst there were businesses in Commuter Village, they were not listed on the community website, even though some of these businesses have been enabled through the fast broadband connections. The fact that they were not listed perhaps indicates that they were businesses which happen to be located at this location rather than seeing themselves as an integral part of the geographical community. This broadband connection had existed only just over one year at the time of study and so it is likely that it had not yet been widely used.

The people living in Commuter Village often worked in the oil industry, for which Aberdeen is the Centre, about 13 miles away. Many were therefore engineers and members of a wealthy local elite with high salaries. Their privatised lifestyles and the way in which they use Internet are cemented by the fact that they were likely to live in large detached houses. The local pub had recently closed and been turned into an upmarket Indian restaurant and it is not clear if this would act as a local community hub in the same way that the pub did. However, it did provide a meeting point when the community broadband initiative was being organised. The lack of community businesses probably reflects the fact that Aberdeen is not far away and even closer (about three miles) is a small town which already has many of these facilities.

Using the same method of searching Facebook, we only found four pages for Commuter Village. One of the pages was for the village, but based upon the auto fill with Wikipedia. Another site was for a real estate business, selling new homes in the area. The only community based sites were for a book club and the school bus to the local academy.

There are only four websites related to the Commuter village which qualified for examination. Two were community websites - the community broadband project homepage and a blog following the project homepage. The other two websites were for local businesses -one for the Indian restaurant and another for a company which delivers an ironing service. Hence, websites were focused mainly upon services and community activities were missing.

Young people in Commuter Village, like their parents, used ICT in a more privatised way by downloading music or movies or engaging in online games. People's networks in Commuter Village were generally with those outside of the village rather than inside. Although Commuter Village had no community website, no history website or as strong a presence offline, the importance of online communication was nevertheless stressed as we shall see in the next section.

Commuter Village, therefore, by contrast with Peninsula Village had few public meeting places and the geography of the village encouraged people to rely on the local town and city for their social activities. There was correspondingly little online public presence linked to social cohesion. But did this mean that ICT was irrelevant for communication within the village? As we shall show, ICT nevertheless played some part in the re-embedding of social relationships.

\section{Social integration: Social networks on and offline}


We consider three elements of social integration: social networks, a sense of belonging and working for the common good. In this section we look at each in turn taking into account both online and offline interactions.

One of the main ways in which social integration can evolve is through social networks. For exploring social integration we looked at the role of social networks and social capital. These networks operated through the various local associations and through communal activities such as organising a clean up campaign once a year. Bridging social capital in Peninsula Village took place not only within the community but between the community and the wider world on account of the good social networks of the various residents. This included networks to writers, artists and film makers as well as links to local Universities and to the local and regional Councils. For Commuter Village this bridging social capital mainly connected individuals with broader communities outside of the region and meant that links to the local community were more shallow.

Bonding social capital was enhanced within Peninsula Village by the fact that all children attended the same local school, caught the same school bus and used the same nursery prior to going to school. In Commuter Village the fact that children could attend a number of different public and private schools in the region was a further reason for the lower levels of linkage between the different members of the community at a locational level. Therefore in Commuter Village the bonding social capital was not centred around the community in the same way, so although people might belong to clubs and organisations, these were not likely to be situated in the community itself. There was little in the way of social spaces available for the people to use such as a church, village hall or pub and some commented that the pub had changed in character since it turned into a restaurant, no longer functioning as a community centre. The common green where people walked their dogs was seen as a meeting place and somewhere where people could interact, although there was some ambivalence as to who was responsible for maintaining it.

I know my next door neighbour just [emphasis] to talk to, but I've never had more than a paragraph conversation. And l've never talked to anyone else in the street. Now there's a shared field, a small strip of land behind the 12 houses; there's a communal area. And I walk my dog there every day. And there's a number of people with dogs, but everyone watches to see who is out with their dog, and then waits until the other dogs end, before they go on their walks. So instead of being a community area where you spend time with people, it's almost an unspoken schedule....... I've had more written or email communication with the neighbours than I have had verbal, everyday conversations. (Male CV)

The local children must attend school in either the local town or commute to Aberdeen. Without even a local shop, or public transport, residents were forced to travel by car for all their basic services and a number of people commented on this. However, they also remarked that the broadband had provided educational opportunities as parents no longer had to drive to another village in order for their children to connect with Internet and do their homework.

Despite this lack of social contact, some members of the Commuter Village did spend time with their neighbours in more informal capacity. There were Commuter Village Facebook pages and in interviews, informants stressed how important it was for them to make friends and organise events through Facebook. However, the Facebook pages were private with restricted access, so we were unable to find out what they contained and this implied social closure rather than wider integration. Nevertheless, private Facebook pages could indicate community cohesion of a different kind. In 
addition, emails were used for communication, even with close neighbours, which reinforced local social relationships, but may have undermined face-to-face ones.

For young people, bonding social capital through using online communications was a normal part of life, but it did not necessarily bond them to the local neighbourhood, but rather to friends who lived in the local town or from school. One respondent reflected on the fact that these online relationships probably weakened rather than strengthened social bonds in the locality. For older people too, much of the time online is spent communicating with personal networks outside of the community, for example through "Friends Reunited". Even neighbours were more likely to communicate by email.

It is indicative of the Commuter Village that privacy within community was stressed:

The ideal community for me is a safe community, where you know people are looking after one another, but it's not intrusive. So, if for example, if somebody wanted to organise street parties or force events, I wouldn't enjoy that. Because I'd feel like I wasn't participating and I'd feel like I should, and then I'd feel guilty and all that stuff. So I would like a caring community that understands people need their individual spaces. (Male, CV)

In terms of bonding social capital, one part of Peninsula Village consisted of a dense network of family ties among the longer term residents going back a number of generations to the fishing community. However, incomers have also become relatively well established connected by friendship links and shared enterprises such as the film festival and the New Year dip. Their ties were often based upon bringing up children in the community using common childcare facilities.

By contrast, most residents of Commuter Village were relatively recent arrivals and from highly mobile professions, so they maintained their networks outside and beyond the village. One of the factors attracting them to the area was the fast broadband services, which they also commented approvingly, had led to a rise in house prices. These services enabled them to better connect with friends, relatives and work colleagues in remote locations. Since those working in the oil industry are often working at remote locations around the world, this opportunity for global networking was seen as a great advantage. Moreover, Facebook and email provided a way for people who knew each other only passingly to get together and arrange barbeques and other private social activities.

We've all found each other on Facebook, we all started talking to each other on Facebook. And we've been invited to barbeques, so the network of people you know grows... it's a diverse population, from all sorts of different backgrounds. And they're very sociable and alcohol seems to bond them together. It seems to be partying type of thing.. and there's a big field at the back of CV, so it is kind of used like a social area. (Male CV)

Therefore, both in Commuter Village and in Peninsula Village, social networks were important and were facilitated through ICT communications. However, in Peninsula Village these were focused more on the location, whilst in Commuter Village, they tended to link to various personal communities that were unlikely to be linked to the Village. Social groups within each village - for example, young people, tended to use information in different ways to other generations; the role of ICT was differentially incorporated in their day-to-day lives.

\section{Social integration: a sense of belonging}


Another aspect of social integration was the creation of a sense of belonging or identification with the place. Both communities evinced a sense of belonging to the community. However, whilst in Peninsula Village this tended to manifest itself as a commitment to the community itself,

There's lots of projects in Peninsula Village, it's a very good close-knit village there where when anyone does something, they do try and get that mix of everyone being invited along, and I guess when you're also in these committees you're in the know-how. We're doing another project, Peninsula Homes and Heritage, and we started that, and that is about we'll go along on Thursday, we'll scribe about working with the Older People's Club, they need 60 to 100, and we're very closely - I mean I'm really fond of the older people in our community, and very fond of them to see the young people in a positive light. So we will be doing some scribing and we will be listening to memories about some of the houses and the young people will receive these memories, and there's a number of events that will happen which will be a lot of intergenerational work. ........ we'll have young people educating older people in the community on how to use your mobile phone, how to use computers, so we do do a lot of work with different ages. (Female PV)

In Commuter Village respondents stressed rather the value of the landscape and the local amenities rather than the sense of community.

I mean unfortunately there's no services in the village really in terms of shops or anything, or post-office and stuff, which is a shame. There used to be a post-office and a shop. There was the pub, the Boar's Head, which was great. I could walk there from my house. Now that's gone to a Boar's Head Indian Restaurant, so not ideal, but still has a bar, so that's ok. So Commuter Village is not really the draw for us, I mean the draw is the rural environment that we live in, so I mean that's just fabulous. And I just love it, you know, we stand in the middle of the countryside really, surrounded by barley fields and pastures and forests and stuff (Male, CV).

However, exploring a community online was seen as a relevant way to get to know a place prior to moving there. As one respondent said "So once I started thinking of Commuter Village as a home, I started to look at the website a little" (Male CV). For people in Commuter Village, using broadband enabled them to work from home and advantages such as shopping or watching films were stressed as well as skyping with friends and relatives. For some it was a way of developing self employed enterprises and consultancies.

The role of community heritage provided a sense of connectedness which all could share in Peninsula Village, but this sense of historical cultural heritage had not been developed in Commuter Village. Cultural heritage can be an important way in which place identities are constructed and this is increasingly centred around online or digital resources (Tait, et al., 2013; Tait, et al., 2011). Community heritage activities were visible in Peninsula Village but not in Commuter Village. In Peninsula Village, a much frequented website was one devoted to historical heritage, where pictures and stories from the past were posted and shared. Community heritage brought together the different elements of village life providing information, photos and oral history testimonies both online and in exhibitions in the community as a place, thus contributing also to system integration. An active local history society met once a month and on the occasion we attended, it hosted some forty people. A number of historical buildings have been restored through fund raising around this topic and these are staffed by volunteers on the days they are open or converted to community use. 
One is a hostel with performance space and another is an art gallery and studio. Local historians have contributed books and other publications to this endeavour and there are commemoration plaques to significant historical figures on some of the well restored and preserved historical buildings. Those in Commuter Village valued the peaceful rural landscape and the value of their own houses but did not connect this to a sense of history of the place, perhaps because their own connection to it was relatively recent and a sense of history was not encouraged by their professional lives.

A sense of belonging was also fostered by communal events in Peninsula Village. These included the New Year dip which involved running into the sea at New Year - something in which many people joined in and it was commemorated by a film on the Community website. Other communal activities involved performance of an opera written by a local composer and performed by the children of Peninsula Village, again commemorated on a public broadcast and a CD. Finally the Film Festival was organised by the local film society to bring films and directors to the area during the winter. None of these things existed in Commuter Village, where the local towns probably provided enough cultural events for those who were interested.

Therefore there were different orientations to the past and a different sense of identitification with place in the two villages.

\section{Social integration: The common good}

Social integration is expressed through a commitment to the "common good". Many people in Peninsula Village had a lot of commitment to the common good and worked as volunteers in various community activities such as the local museums (there were three of them) or with various community associations. There were a great many such associations, such as an old persons club, linked to the community and a number of social enterprises - for example a local café and a proposed retirement home - so that doing something for the community was seen as a common practice.

In Commuter Village, by contrast, there was some difficulty in getting people involved in community life and the social entrepreneur who set up the broadband relayed this experience:

You know, I've experience a lot of anti community spirit here. For example, I was asking a farmer whether I could put a relay site (for the community broadband), a very small relay site, on the side of a disused barn. And he said "Oy, don't put any rubbish on the side of my barn!" and I said "but it's a community project" and he said "I don't care about that. Why should I care about CV or any other community?" And he just closed the door in my face. Well, you know, I had quite a lot of that at the beginning. (Male CV)

In Peninsula Village there was much more obvious dedication to common projects. An example would be the Cheese Shop initiating a community arts event whereby there was an "open house" and people can go from house to house enjoying artistic experiences such as joining in with music. Other events such as a film festival and crime writers weekends were organised for those both inside and outside the community. However, the work of organising these events is spread across a number of people and organisations, whilst in Commuter Village it was acknowledged that the kinds of community enterprise that took place depended upon the initiative of just one or two people and 
could collapse if these people were no longer able to do them. A festival in the field behind the village was organised intermittently depending upon the time and willingness of another local resident, who started this as a celebration of his fortieth birthday, but this was also mainly a private event. Hence the way in which community organisation works differs markedly in the two localities and this tends to be reflected in the online communications.

A commitment to the common good is an important element of the social integrational aspects of social cohesion. This took different forms in the different localities and the more isolated nature of Peninsula Village perhaps encouraged volunteering and subscription to local events in that location. However, the influx of a bohemian creative class bringing idealism in terms of community relations and a commitment to making them work facilitated this sense of strong moral commitment. People in Commuter Village, by contrast, were more interested in having a peaceful life untroubled by demands and pressures from the local community but providing them with privacy and time to pursue their own interests. Online communications enabled and helped to recruit people to community activities in Peninsula Village, whilst these were lacking in Commuter Village.

\section{Conclusions}

We can see that social cohesion was manifested in very different ways in the two communities in question. Despite being of similar size and composition, the social relationships were very different. In Peninsula Village the commitment of the local creative class (which we have termed "bohemian") to developing a sense of solidarity was manifested in numerous organisations and voluntary activities. In Commuter Village, the more privatised lifestyles and identification with activities in nearby cities and towns rather than with the village meant that it was difficult to raise enthusiasm for a social enterprise and residents led more private lives from their own homes. Nevertheless online communications were important for residents to pursue their personal and professional lives and were also used to contact neighbours through a process of local re-embedding of social relationships.

ICT was used in Peninsula Village to bridge social divisions and self-consciously create an online cohesive community presence. In Commuter Village, the use of ICT tended to reflect private networks and preoccupations, even when these were locally based (for example getting together for a barbeque). The layering of communities through changing populations, cultural and generational divides meant that some people connected more to the place in which they lived, using ICT to reembed their social relationships, whilst for others this was a way of connecting to outside or preexisting networks, which might even have undermined local social cohesion. Hence, we can say that ICT might in some ways have encouraged local social cohesion, but in other ways undermined it, depending upon how it is used. We have tended to focus upon the former in this article because it was the focus of our interest, but was should bear in mind that because much of the ICT communication was public, it was a way of connecting the community to the outside world rather than being inwardly focused. Here we have focused upon publicly accessible ICT for our analysis, which is necessarily only part of the picture.

The study of the two Scottish rural communities illustrates the fact that social cohesion can be built with the help of ICT given the right circumstances. The creation of system integration can be associated with offline meeting places, but also online sites that connect different interests and cultural groups. It can help to foster a sense of social integration through social networks (both 
bridging and bonding), through enabling a sense of identity, for example through communal events or interest in historical heritage and it can encourage commitment to the common good by creating new opportunities for volunteering and participating in local activities. Although we developed these theoretically derived analytical categories for analysis of complex interrelations between online and offline communications, in practice they tended to overlap one another. For example, the communal website in Peninsula Village was a also a vehicle for creating a sense of identity and enabling commitment to the common good, whilst in Commuter Village the communal spaces encouraged more private email and Facebook networks. Therefore these analytical categories of social and system integration were a good starting point for the analysis, but in practice quite difficult to disentangle..

Indeed we could argue that there is an important methodological advantage for studying communities using online presence in the way that we have, over more traditional methods. The online presence shows how communities represent and imagine themselves in ways that are unelicited. Furthermore, the detailed research of social media and other online sites can help to reveal the idea of "place" in social, cultural and economic relationships as different community interests (business, service, civil society etc.) represent themselves in different media and in different ways.

In this community-building enterprise, ICT can play an important part. ICT enables various elements of the community to connect to one another and the community to present itself to the world, ensuring both system integration at the level of the community and social integration in the way individuals were embedded in it. However, the way in which ICT is shaped depends upon the characteristics of the different residents and how their social relations have evolved. We are not arguing here for causality - ICT does not create social cohesion nor vice versa. Rather we are seeking to show how information and communications technology is intertwined with social life in rural communities in ways that co-evolve. It might be objected that we should take an unconnected community to provide a true counterfactual contrast for the use of community ICT. However, apart from the difficulties of finding a community that is not touched by digital communications, this would be unable to capture the multiplicity of community communications and how these takes place. Whilst we are not arguing that these communities are typical, they do represent contrasting forms of rural life in the contemporary British countryside.

In this process there is a re-embedding of social relationships using various community initiatives online as well as offline so that a sense of community can be developed. In one community (Peninsula Village) this took the form of developing local social cohesion and bridging community cleavages through multiple and diverse forms of communication both online and offline. In Commuter Village, whilst digital communications were also important to residents, they tended to reinforce separation between residents, so that locality based communications were far more limited. Therefore, although ICT can help to promote social cohesion, this needs to be seen in terms of the structure and development of the community as such. 


\section{References}

Abbott, P. and Wallace, C., (2012). 'Social Quality: A way to measure the quality of society'. Social Indicators Research, 108 (1):153-167.

Abbott, P., Wallace, C. and Sapsford, R., (2016). The Decent Society. London and New York:

Routledge.

Anderson, B., (1983). Imagined Communities. Reflections on the origin and spread of nationalism. London: Verso.

Berger Schmitt, R., (2002). 'Considering social cohesion in quality of life assessments: concept and measurement'. Social Indicators Research, 58:403-428.

Bosworth, G. and Willett, J., (2011). 'Embeddedness or Escapism? Rural Perceptions and Economic Development in Cornwall and Northumberland'. Sociologica Ruralis, 51 (2):195-214.

Bourdieu, P., (1983). 'Forms of Capital'. In: Richardson, J. (ed). Handbook of Theory and Research in the Sociology of Education. New York: Greenwood Press.

Bourdieu, P., (1984). Distinction. London: Routledge \& Kegan Paul.

Calhoun, C., (1998). 'Community without Propinquity Revisited: Communications Technology and the Transformation of the Urban Public Sphere'. Sociological Inquiry, 68 (3):373-397.

Champion, T. (ed), (1989). Counterurbanisation: the changing pace and nature of population deconcentration. Sevenoaks: Edward Arnold.

Crow, G., (2002). Social Solidarities. Theories, Identities and Social Change. Buckingham, Philidelphia: Open University Pres.

Dragolov, G., Ignacz, Z., Lorenz, J., Delhey, J. and Boehnke, K., (2013). Social Cohesion Radar.

Measuring common ground. An international comparison of social cohesion. Gutersloh: Bertelsmann Stiftung.

Durkheim, E., (1964). The Division of Labour in Society. New York: Free Press.

Dutton, W., H. and Blank, G., (2012). Next Generation Users: the Internet in Britain. Oxford Internet Survey Report. Oxford: Oxford Internet Institute.

Ellison, M. (ed), (2012). Reinventing Social Solidarity across Europe. Bristol, Chicago: Policy Press.

Florida, R., (2002). The Rise of the Creative Class: and How It's Transforming Work, Leisure,

Community and Everyday Life. New York: Basic Books.

Giddens, A., (1991). Modernity and Self-Identity. Cambridge: Polity Press.

Granovetter, M., (1974). Getting a Job: a study of contacts and careers. Cambridge, Mass.: Harvard University Press.

Guibernau, M., (2013). Belonging. Solidarity and Division in Modern Societies. Cambridge: Polity. Halfacree, K., H., (2008). 'To revitalise counterurbanisation research? Recognising the international and fuller picture'. Population, Space and Place, 14:479-495.

Huysman, M. and Wulf, V. (eds), (2004). Social capital and information technology. London, Cambridge Mass.: MIT Pres.

Ingold, T., (2000). The Perception of the Environment. London and New York: Routledge.

Jedrej, C. and Nuttall, M., (1996). White Settlers. The Impact of Rural Repopulation in Scotland.

London and New York: Routledge.

Jones, H., (2013). Negotiating Cohesion, Inequality and Change. Uncomfortable positions in Local Government. Bristol and Chicago: Policy Press.

Larsen, C.A., (2013). The Rise and Fall of Social Cohesion. The construction and deconstruction of social trust in US, UK, Sweden and Denmark. Oxford: Oxford University Press.

Lin, N., (2001). 'Building a network theory of social capital'. In: Lin, N., Cook, K. and Burt, R., S. (eds). Social Capital. Theory and Research. New York: Walter de Gruyter.

Lin, N., Cook, K. and Burt, R., S. (eds), (2001). Social Capital. Theory and Research. New York: Walter de Gruyter.

OECD, (2008). OECD Rural Policy Reviews: Scotland, UK. Paris: OECD. 
Pahl, R.E. and Spencer, L., (2004). 'Personal Communities. Not simply families of fate or choice'. Current Sociology, 52 (2):199-222.

Phillips, D., (2006). Quality of Life. Concept, Policy, Practice. London and New York: Routledge.

Pigg, K., E. and Crank, L., D. , (2005). 'Do information technologies promote rural economic development?'. Community Development, 36 (1):65-76.

Putnam, R., D., (2000). Bowling Alone. The Collapse and Revival of American Community. New York: Simon and Schuster.

Putnam, R.D., Leonardi, R. and Raffaella, N., (1993). Making Democracy Work. Civic Traditions in Modern Italy. Princeton, N.J. : University of Princeton Press.

Rainie, L. and Wellman, B., (2012). Networked. The New Social Operating System. Massechusetts: MIT Press.

Savage, M., (2010). Identities and Social Change in Britain since 1940. The Politics of Method. Oxford: Oxford University Press.

Spencer, L. and Ritchie, J., (1994). 'Qualitative analysis for applied policy research'. In: Bryman, A. and Burgess, R.G. (eds). Analysing Qualitative Data London and New York: Routledge.

Stockdale, A., Philip, L. and MacLeod, M., (2013). 'Retirement Transition Migration: Impllications for Rural Development'. Journal of Rural and Community Development, 8 (3):303-320.

Tait, E., MacLeod, M., Beel, D., E., Wallace, C., D. and Mellish, C., S., (2013). 'Linking to the Past: An Analysis of Community Digital Heritage Initiatives'. Aslib Proceedings, 65 (6).

Tait, E.J., Wallace, C., Mellish, C.S., McLeod, M. and Hunter, C.J., (2011). 'Creating and sustaining rural digital heritage resources using online databases'. Supporting Digital Humanities. Answering the Unaskable. Copenhagen, Denmark.

Townsend, L., Sathiaseelan, A., Fairhurst, G., Wallace, C. and Anderson, A.A., (2013). 'Enhanced broadband access as a solution for the social and economic problems of the rural digital divide'. Local Economy.

Townsend, L., Wallace, C. and Fairhurst, G., (2015). "Stuck out here': the critical role of broadband for remote rural places'. Scottish Geographical Journal.

Townsend, L., Wallace, C., Smart, A. and Norman, T., (2015 ). 'Building virtual bridges: how rural micro-enterprises develop social capital in online and face-to-face settings'. Sociologica Ruralis. Turkle, S., (2013). Alone Together: Why we expect more from technology and less from each other. Philadelphia: Basic Books.

Wallace, C., (2013). 'Is Social Quality enhanced by information technology and communications ? '. International Journal of Social Quality. 


\section{Information technology and social cohesion: a tale of two villages}

\section{Introduction}

The countryside is being transformed by the possibilities offered by Information and Communications Technology (ICT) to enable people to live and work remotely but also to interact with their local communities in new ways. For example, locational associations and informal groups such as football clubs, dancing clubs or book clubs can communicate their activities and Local Councils can provide a virtual information hub. ICT enables local communities to be created through online and offline interactions which have implications for the kinds of social cohesion that evolve. The paper considers how these local social relations are played out in new forms through digital interactions.

Social theorists have long pointed to the disappearance of traditional communities in the countryside and elsewhere through the disembedding of social relationships (Giddens, 1991) in favour of communities of choice and personal communities which are less likely to be locational (Pahl and Spencer, 2004).This disembedding of social relationships and traditional communities in time and space is further enabled through digital communications that can create new communities of interest and affect which are not localised at all (Rainie and Wellman, 2012) and are available $24 / 7$ at the click of a mouse or poke of a touch pad (Turkle, 2013). Hence, communities without propinquity take on new dimensions through ICT (Calhoun, 1998). However, people still live in local communities in which social relationships are meaningful and important and it is the re-embedding of these social relationships within a locality which are the focus of this study.

Digital communications also play an increasingly important part in this process as the community can be represented and "imagined" online in different ways. However, within communities various social layers interact with digital technology in different ways leading to different forms of social cohesion and different relationships to the community of place. Digital communications are usually seen as an integral part of the development of urban areas (see for example the recent digital cities catapult https://futurecities.catapult.org.uk/). Yet rural communities are interesting ones in this respect because their relative isolation and dispersion make ICT perhaps even more important (Townsend, et al., 2013). People might seek to make a living in the countryside, by setting up businesses or by commuting or remote working (Bosworth and Willett, 2011), but it is often quality of life that they are seeking, which can include quality of community life as they perceive it (Champion, 1989). They join people for whom the countryside is a source of more traditional forms of livelihood (such as farming or fishing) creating a series of socio-economic and cultural layers (Halfacree, 2008; OECD, 2008). The constant churn between in-coming and out-going populations in the last decades as young people move away to find work or education and older people move in to retire (Stockdale, et al., 2013) may make it difficult to easily distinguish between "incomers" and "locals" (Jedrej and Nuttall, 1996), although these distinctions might nevertheless hold a cultural or social salience. The tradition of community studies mainly focused on social relationships in more settled communities that were geographically bounded (Crow, 2002). However, new social relationships created by mobile residents and information communications suggest that many dimensions of community life, including social cohesion, need to be reconsidered. Nowadays, rural communities are ones of choice rather than necessity. But what sort of communities are they? 
The purpose of this paper is to look at how people create a sense of community and social cohesion in a local setting. It considers the role of ICT in enabling them to do so and how new kinds of community are thus created. ICT means that people do not need to leave their networks behind them when they move but there might nevertheless be re-embedding of social relationships at a local level. In doing so, people create their own sense of "elective belonging" (Savage, 2010) in their attachments to the places they have chosen to live and the social imagining of those places (Anderson, 1983). The richness of local social relationships, which we term social cohesion, are important for the "quality of life"(Phillips, 2006) to which social cohesion contributes (Abbott and Wallace, 2012).

\section{Theory: local communities and social cohesion}

Although social cohesion has a long history in social sciences, it has been more recently adapted to provide a framework for social policies at national and European levels (Ellison, 2012; Jones, 2013; Larsen, 2013) and is usually analysed at a national level, often in terms of quantitative indicators (Berger Schmitt, 2002). Deriving from Durkheimian sociology, social cohesion refers to the social bonds and social norms that hold society together (Durkheim, 1964) and has been recently operationalised through indicators to measure social networks, a sense of identity and the commitment to the common good (Dragolov, et al., 2013). So far, few people have tried to look at contemporary forms of social cohesion either qualitatively or at a local level and none have done so by considering ICT.

David Lockwood provides a framework for understanding social cohesion in terms of system integration:

"Whereas the problem of social integration focuses attention upon the orderly or conflictful relationships between actors, the problem of system integration focuses on the orderly or conflictful relationships between the parts of a social system." (Lockwood, 1992: 400)

In other words, system integration can be seen to relate to the community as a whole and the relationships of the different parts within it, whilst social integration refers to the way in which individuals are linked to the community through social inclusion (Abbott, et al., 2016).

But how can it be operationalised empirically at a local level? Here we consider system integration as the relationship between different structural elements of the local social system - how cleavages of social classes, age, divisions between what are perceived as "incomers" and "locals" are bridged. We consider social integration as the way in which individuals are connected to the local community through social networks, social capital, a sense of belonging and working for the common good.

Beginning with system integration, social cleavages can be particularly acute in small communities where people live in close proximity, but are themselves dynamically changing. They can also be lived out in virtual communities as different social groups use ICT and interact with their communities in different ways. Cleavages according to income as well as culture might be found but also according to age as the divide emerges between those who use a variety of communications media and those who use only limited media or none at all (although the latter group are rapidly disappearing) (Dutton and Blank, 2012). Here we can identify offline sites of interaction in the form of meeting places such as greens and streets for casual interaction, commercially provided community hubs such as pubs, shops and cafes or collectively organised spaces such as meeting 
halls, notice boards and museums. The density and nature of civil society organisations such as youth clubs, local history associations and religious organisations can be greatly augmented through online communications on which they increasingly depend (Huysman and Wulf, 2004; Wallace, 2013). Online meeting spaces encouraging system integration can also be websites which provide collective resources and information. However, many of these sites are provided officially through local authorities and it is not clear how much community activities really form part of this virtual space or how much local residents are able to engage with it. Locally produced radio and TV stations, as well as paper or online newsletters, help to bridge this divide between official communications and citizen participation. In rural areas, the local Community or Parish Council can help to make these collective spaces into ones that engage residents but their degree of activity and representativeness of local interests is variable.

Turning now to social integration, this refers to the way in which people are connected into the community at an individual or group level and can be explored both online and offline. An important element of this is social networks binding people to a community and thereby generating social capital (social capital being seen as the added social value produced by networking). This includes "bridging social capital" that can link to others outside personal networks (Lin, 2001; Putnam, 2000) and "bonding social capital" that can help to reinforce more affective social relationships. Both forms of social capital are important for generating social cohesion. Social capital can potentially be augmented by ICT communications, including the weak ties that enable people to " get things done" (Granovetter, 1974) as well as the strong ties reinforced by social media such as Facebook, WhatsApp and texting. The synthesis of bridging and bonding social capital assisted can be even more strongly reinforced in rural areas on account of the overlapping of multiple social ties (Townsend, et al., 2015 ).

A second element of social integration is the feeling of belonging to the community (Dragolov, et al., 2013). This sense of belonging, identified at a national level as a powerful emotional commitment to a territory and its related community (Guibernau, 2013), could also be found at the local level in some communities that generate local loyalties and elective affinities. In some cases it can be the effect of the physical landscape that has emotional implications (Ingold, 2000), but social solidarities are cemented by a sense of loyalty and commitment to the group, which some contexts foster more than others (Crow, 2002). This sense of identification can be explored through subjective perceptions of individuals but also through the multiple ways that the evocation of the locality is an explicit focus of online communications.

A third element of social integration as a factor in social cohesion is a commitment to the community and the "common good" for which people might be prepared to invest time, capital or other resources (Dragolov, et al., 2013). Commitment to the community as a common good is based on altruistic notions of the worthiness of local causes and putting collective interests above individual ones - although these activities can also be vehicles for furthering individual self-interest as Lin demonstrates (Crow, 2002; Dragolov, et al., 2013; Lin, et al., 2001). For Putnam it is this collective good that is fostered through social capital to foster "civic mindedness" which is also the basis for prosperity and democracy (Putnam, 2000). In his studies, it is this civic mindedness which distinguishes the prosperous North of Italy from the "backward" South (Putnam, et al., 1993). Social capital is therefore generated through activities like volunteering, working for community-oriented goals as well as the nature and extent of local social enterprise. Although Putnam does not mention 
social enterprise, these kinds of projects which draw on local social activism and generate social and economic capital for the community can be seen as important elements of local social cohesion. Many studies have argued that participation in local civil society activity is also enhanced by digital communications (Pigg and Crank, 2005)

All of these elements of social cohesion illustrate the intertwining of online and offline social relationships in everyday life. The kind of online presence and activities that it suggests may give an idea about the nature of social cohesion in a particular locality. In this respect online research can greatly augment the more traditional social science methods such as ethnography and interviews, as we shall show.

\section{Methods}

Two communities in Scotland were selected for study: one a relatively remote rural community set at the end of a peninsula with a strong tradition of community engagement and the second a village within easy commuting distance of a major urban settlement. The two villages, which we will term "Peninsula Village" and "Commuter Village" are of comparable size with around one thousand inhabitants. The first community had enjoyed online communications for some twenty years, being one of the first localities in Scotland to be linked to Internet and later to high speed broadband through a fibre optic cable set up by a local private company. The second community initiated their own fast broadband access through a social enterprise only two years prior to the study taking place, although they were previous connected through slower landline telecommunications infrastructure more common in rural areas. The two communities represent contrasting experiences of rural living in contemporary Britain.

Fieldwork and interviews were carried out between 2012 and 2014 by three members of the team. The methods employed took two main forms: interviews and participant observation in the communities and analysis of public online communications associated with each place. The former involved interviews with key informants in both communities including the social entrepreneurs who set up the broadband networks, youth leaders, local councillors, local businesses and civil society participants in clubs and organisations. These helped us to identify different community fractions and so we endeavoured to interview representatives from them: younger and older people; people from different social class communities; recent arrivals and more long established residents. These community fractions represented cultural configurations recognised in the communities themselves - so for example the cultural distinction between "incomers" and "long term residents" was one such distinction even if it did not entirely map onto length of residence and in practice even long term residents tended to come, go and return. Cultural differentiations were likewise reflected in local assessments such as between one end of the village and another or between membership of different clubs and associations, or frequenting of different social hubs. The reproduction and salience of these kinds of cultural differentiation reflect important and meaningful divisions for people with different forms of habitus (Bourdieu, 1984; Savage, 2010). Some of these were digitally active, some less so and some not at all. Around twenty respondents from different socio-cultural groups were interviewed in each locality over a period of months. Participant observation was carried out in community hubs such as restaurants, shops, cafes, festivals and pubs. 
In addition an analysis of websites and online participation was carried out by comparing online presence during the same period (carried out during August 2013). The web analysis took three forms. First, the community websites were accessed and analysed in terms of their content based on the approach to social cohesion discussed above. Second, a Google search for sites related to the name of each locality was carried out to understand the extent to which the locality itself was a market for online communications. Thirdly, social media was analysed by searching for Facebook sites associated with the name of each location. Together these methods aimed to capture online presence although they could not be exhaustive since they covered only public sites where the name of the place was included.

Interviews were transcribed and analysed using the Framework method of qualitative analysis and to this was added the classification of online activities (Spencer and Ritchie, 1994). This combination of resources provided a cascading framework of analytical categories for system integration (relationships between different groups, common sites of interaction) and social integration (social networks, a sense of belonging and commitment to the common good) that enabled us to merge the different online and offline methodologies.

Since many rural communities lack good broadband connections, and are indeed falling further and further behind their urban counterparts (Townsend, et al., 2013) we have focused upon villages that had fast broadband connections. They are therefore not necessarily typical of other rural areas but fitted the purpose of our study.

\section{Two Villages with ICT}

Official statistics provided by the Scottish Government using Scottish Indicators of Multiple Deprivation that can be broken down to postcode level, indicate that both communities are relatively affluent communities with low levels of deprivation on average (http://www.sns.gov.uk/). House prices were high, reflecting the fact that they are both desirable places to live and Peninsula Village had a slightly older population than Commuter Village. Commuter Village has a higher proportion of families with young children than the national average. Social problems related to drugs and crime were low in both villages although both contained pockets of deprivation with 10 per cent being income deprived in Peninsula Village and 5 per cent in Commuter Village. Furthermore, there are high levels of social housing in Peninsula Village, which were concentrated into one end of the village, creating a geographical as well as a social divide.

Peninsula Village had been a rundown fishing village since the nineteenth century, but was gentrified with housing improvement grants from the 1980s onwards with an influx of "bohemian" middle class bringing high levels of cultural capital even if they did not necessarily have high incomes (Florida, 2002). Although Florida (2002) has looked at how this can help to transform urban neighbourhoods into desirable and trendy places through the intensity of cultural activity that these groups bring with them, it would seem that this is also applicable to some rural areas as well. The creation of good Internet access since the 1990s and later high speed broadband was one of the initiatives of these incoming entrepreneurs, since creative industries depend increasingly upon digital media (Townsend, et al., 2015), but it opened the way for other digital and creative enterprises to locate there. It is now a tourist destination with heritage attractions located 23 miles from the nearest large town at the tip of a peninsula. 
Commuter Village was largely a farming community until the advent of the oil industry in Aberdeen brought in wealthy middle class home owners, often living in large, new, detached houses or in recently renovated accommodation. The influx of a mobile community, often with technological expertise on account of their professions and demanding high levels of connectivity to pursue their work and their social interests prompted the move to create a fast broadband connection through the initiative of local people. However, Commuter Village is characterised more by technological than cultural capital as it did not enjoy the high level of cultural life in terms of festivals, events and arts and crafts activities (Bourdieu, 1983).

Both villages reflected an influx of the incomers with different perspectives and aspirations over a period of decades and they are examples of different kinds of rural living in contemporary Britain. The villages were selected primarily on account of the availability of fast broadband connections since this was an integral part of the study we carried out.

\section{System integration : bridging social cleavages}

Social cohesion at the systemic level involves the integration of different social cleavages through civil society and common sites for interaction both on and offline. Calhoun (1998) mentions this in terms of abstract, bureaucratic social relationships, but we can also apply this in ways that more relevant for local social interactions. In Peninsula Village there were many opportunities for making these connections. There were many communal points of interaction. The Post Office, the supermarket, the community bakery and the "Emporium" selling souvenirs, books (both new and second hand), and postcards as well as craft work operated as community hubs with a variety of notices in the windows. Notwithstanding the rather isolated location of the community, there were many festivals and events that attracted people from outside. A local hotel and two thriving pubs attract different groups of regular and occasional customers. A local restaurant which began as a social enterprise, acts as a meeting point for different elements of the community including young and old and helps to host community events. Two local Universities have restored buildings within the town and stage events there. The traditional architecture of this former fishing village with densely packed houses, often in terraces fronting onto the streets and alleyways, encourages casual encounters with neighbours. Many of the civil society activities were organised through the Community Arts Trust which organised regular events. There were clubs targeted at older residents and a youth café, partially funded through a legacy left to the town.

There were nevertheless social cleavages in Peninsula Village based upon age and social class. In terms of age, the young people tend to move away from the village in order to go to University, to seek work or more exciting lifestyles, leaving behind an ageing population. However, on account of the sense of security, trust and community spirit (which was acknowledged by everyone we spoke to) people with young children tended to move to the village, including returnees. The different generations of young people all attended the local school and some of them formed age cohorts who stay in touch through Facebook even when they have left the area, although these were generally divided between those who went to University and those with lower educational qualifications dependent upon more local opportunities. The age-specific cohorts sometimes give themselves distinctive identifying monikers (such as "Peninsulans On Tour" ). Young people were more likely to communicate using smart phones, texting and YouTube, whilst the older people used email. Despite the excellent broadband coverage, young people complained about the poor $3 \mathrm{G}$ 
coverage, which prevented them from using their mobile devices as much as they would have liked (4G was not even mentioned at the time of interviewing). Young people used ICT communications (mainly on their mobile devices) to organise social life, such as parties or meetings and to keep up to date with friends. Communication was continual and one young person talked of texting 2-3 times an hour with her friends and having at least daily Facebook contact. The young people from the youth club had posted a video of themselves on YouTube which had enjoyed 15,000 hits. Even those from the more socially deprived end of town had play stations, Xboxes and mobile devices.

Peninsula village had a well-developed website set up and maintained by the Community Council and reflecting the long period of development of the community since the 1980s. A count of associations mentioned in the website of Peninsula Village included religious worship, a bowling club, Ceilidh Dances, Art Exhibitions (several of them), Craft Fairs, musical weekends and musical events (mostly folk music which has a strong following in Scotland), a Boating Club, Football Club, Tennis Club, Lifeboat Club, Mothers and Toddlers club, Snooker Club, an Allotments and Gardens Society and a Friends of the Church Society. There was a calendar where almost every day was filled with activities and events. Altogether 16 local businesses were listed on the website and there was a special section for Artists and Crafts businesses of which there were also 16. Businesses included a local Brewery, an Antiques Shop and a Cheese Shop selling specialist cheeses and itself a venue for various community events. Under health and fitness were listed salsa dancing, reiki massage, crystal healing and a variety of alternative therapies. It is perhaps the "creative class" (Florida, 2002) that has helped to transform social and cultural relations in this region and attract like-minded people. In fact the community website worked as a form of system integration to bring together all these diverse interests within the local community including different social and age groups, new arrivals and older residents

A search using the village's name on Facebook revealed 87 Facebook groups in the area. However, 60 of those were automatically created by Wikipedia due to users expressing an interest. These auto-pages were most often about local landmarks, nearby towns or historical figures, but the only postings tended to be the description generated by Wikipedia and there were few, if any "likes" among them. Of the remaining 27, the majority (11) were for local businesses, many of them designed to attract tourists. There were also pages for businesses, including the brewery, and two Facebook pages for one of the two pubs. As well as a page for the main hotel, there are four pages for holiday cottages and for the local caravan sites. Three of the businesses were entertainment/activity based, including a music venue, dolphin tours and a ferry for sightseeing. In addition, there were eight pages for community groups, a mixture of sports clubs and cultural or arts organisations and NGOs -including the film society, the Community Arts Trust, the Citizens' Advice Bureau and the cycling club, amongst others. There were five pages about events, including the New Year's ocean dip, a film festival, and community markets

We also carried out a Google search for the most prominent local websites in each of the villages. When putting the name of the Peninsula village into Google, we analysed the first ten pages of results, with the exception of those websites which only had one page dedicated to the village ${ }^{1}$. In this way, we were able to examine 45 websites. Seventeen of the websites were for local businesses. As with the Facebook sites, the businesses tended to be related to the tourist industry. There are two websites for local hotel/bed and breakfasts, as well as four sites for holiday cottage rentals. There are four websites for retail shops, including the post office, the local gift shop, a 
pottery gallery and a cheese store. In addition to the brewery and pub which we found on Facebook, there was also a site for the local café and three businesses associated with the harbour, including the aforementioned dolphin tours and ferry. Finally there is a company which hires out archaeological services in the area.

Twenty six websites, including the official site, were classified as community based. Ten of these groups were for activities, including the boat club, sports council, allotments, the film society and camera club. There were eight websites which related to historical or cultural societies, including building preservation societies. The final eight are a combination of local government, religious and Masonic groups. Finally, there were two websites about annual events - a film festival and a New Year dip in the sea.

The community website in Peninsula Village was itself a source of system integration as it brought together the activities of different groups. It was set up and controlled by the Community Council but with very active participation of the community itself, but was edited and orchestrated by this organisation as an outward and inward facing projection of the community. Social Media was much wilder and less controlled and in this respect, so online presence could also undermine social cohesion. Youth workers and community workers were in fact wary of using Facebook as they claimed that this made young people prey to those who would use this communication media exploitatively and also because gossip tended to inflate into "flaming" online dramas which blew up problems and difficulties rather than resolving them.

Despite the social class divisions and those between incomers and natives, everyone in Peninsula Village commented on the strong sense of community that was to a great extent able to overcome these divisions:

It's a great community, Peninsula Village, it is a fantastic community. I mean it's quite rare as a community. It's quite unique in lots of ways. ...We have a strong community spirit here. (Female PV)

Whilst in Peninsula Village a number of social enterprises had been initiated and levels of volunteering were high, in Commuter Village, the main social entrepreneur had difficulty in enlisting the help of others within the community to set up the Community Broadband (even though in the end it would benefit everyone). He was treated with suspicion by others who wanted financial compensation for using their properties to relay the signal around the area. One farmer refused to co-operate, yet another saw the benefits for his business and co-operated enthusiastically. Another householder objected to a telegraph pole being erected in front of his house. The lack of engagement by a wider group of people has hindered the sustainability of the broadband initiative.

The rather expensive nature of the broadband network that had been set up in Commuter Village ( $€ 100$ per month for the "gold" service, but cheaper for lesser services) meant that this service was more available to the wealthier members of the community and poorer people (even teachers), were not able to subscribe to the gold service. Even the lower level of services at $£ 50$ per month is more than would be charged by many conventional broadband providers.

In Commuter Village the public online presence was very limited. The website contained information about the broadband project and what to do in case of problems, as well as information 
about a heating oil club enabling villagers to get cheaper fuel. The only other listing was about the local school. The Commuter Village broadband was set up through a social enterprise enlisting the support of other householders in the neighbourhood. The resulting superfast broadband connections were mainly used by householders to stream TV or movies and to communicate to relatives through video conferencing connections (people working in the oil industry are often working for periods of time abroad). Whilst there were businesses in Commuter Village, they were not listed on the community website, even though some of these businesses have been enabled through the fast broadband connections. The fact that they were not listed perhaps indicates that they were businesses which happen to be located at this location rather than seeing themselves as an integral part of the geographical community. This broadband connection had existed only just over one year at the time of study and so it is likely that it had not yet been widely used.

The people living in Commuter Village often worked in the oil industry, for which Aberdeen is the Centre, about 13 miles away. Many were therefore engineers and members of a wealthy local elite with high salaries. Their privatised lifestyles and the way in which they use Internet are cemented by the fact that they were likely to live in large detached houses. The local pub had recently closed and been turned into an upmarket Indian restaurant and it is not clear if this would act as a local community hub in the same way that the pub did. However, it did provide a meeting point when the community broadband initiative was being organised. The lack of community businesses probably reflects the fact that Aberdeen is not far away and even closer (about three miles) is a small town which already has many of these facilities.

Using the same method of searching Facebook, we only found four pages for Commuter Village. One of the pages was for the village, but based upon the auto fill with Wikipedia. Another site was for a real estate business, selling new homes in the area. The only community based sites were for a book club and the school bus to the local academy.

There are only four websites related to the Commuter village which qualified for examination. Two were community websites - the community broadband project homepage and a blog following the project homepage. The other two websites were for local businesses -one for the Indian restaurant and another for a company which delivers an ironing service. Hence, websites were focused mainly upon services and community activities were missing.

Young people in Commuter Village, like their parents, used ICT in a more privatised way by downloading music or movies or engaging in online games. People's networks in Commuter Village were generally with those outside of the village rather than inside. Although Commuter Village had no community website, no history website or as strong a presence offline, the importance of online communication was nevertheless stressed as we shall see in the next section.

Commuter Village, therefore, by contrast with Peninsula Village had few public meeting places and the geography of the village encouraged people to rely on the local town and city for their social activities. There was correspondingly little online public presence linked to social cohesion. But did this mean that ICT was irrelevant for communication within the village? As we shall show, ICT nevertheless played some part in the re-embedding of social relationships.

\section{Social integration: Social networks on and offline}


We consider three elements of social integration: social networks, a sense of belonging and working for the common good. In this section we look at each in turn taking into account both online and offline interactions.

One of the main ways in which social integration can evolve is through social networks. For exploring social integration we looked at the role of social networks and social capital. These networks operated through the various local associations and through communal activities such as organising a clean up campaign once a year. Bridging social capital in Peninsula Village took place not only within the community but between the community and the wider world on account of the good social networks of the various residents. This included networks to writers, artists and film makers as well as links to local Universities and to the local and regional Councils. For Commuter Village this bridging social capital mainly connected individuals with broader communities outside of the region and meant that links to the local community were more shallow.

Bonding social capital was enhanced within Peninsula Village by the fact that all children attended the same local school, caught the same school bus and used the same nursery prior to going to school. In Commuter Village the fact that children could attend a number of different public and private schools in the region was a further reason for the lower levels of linkage between the different members of the community at a locational level. Therefore in Commuter Village the bonding social capital was not centred around the community in the same way, so although people might belong to clubs and organisations, these were not likely to be situated in the community itself. There was little in the way of social spaces available for the people to use such as a church, village hall or pub and some commented that the pub had changed in character since it turned into a restaurant, no longer functioning as a community centre. The common green where people walked their dogs was seen as a meeting place and somewhere where people could interact, although there was some ambivalence as to who was responsible for maintaining it.

I know my next door neighbour just [emphasis] to talk to, but I've never had more than a paragraph conversation. And l've never talked to anyone else in the street. Now there's a shared field, a small strip of land behind the 12 houses; there's a communal area. And I walk my dog there every day. And there's a number of people with dogs, but everyone watches to see who is out with their dog, and then waits until the other dogs end, before they go on their walks. So instead of being a community area where you spend time with people, it's almost an unspoken schedule....... I've had more written or email communication with the neighbours than I have had verbal, everyday conversations. (Male CV)

The local children must attend school in either the local town or commute to Aberdeen. Without even a local shop, or public transport, residents were forced to travel by car for all their basic services and a number of people commented on this. However, they also remarked that the broadband had provided educational opportunities as parents no longer had to drive to another village in order for their children to connect with Internet and do their homework.

Despite this lack of social contact, some members of the Commuter Village did spend time with their neighbours in more informal capacity. There were Commuter Village Facebook pages and in interviews, informants stressed how important it was for them to make friends and organise events through Facebook. However, the Facebook pages were private with restricted access, so we were unable to find out what they contained and this implied social closure rather than wider integration. Nevertheless, private Facebook pages could indicate community cohesion of a different kind. In 
addition, emails were used for communication, even with close neighbours, which reinforced local social relationships, but may have undermined face-to-face ones.

For young people, bonding social capital through using online communications was a normal part of life, but it did not necessarily bond them to the local neighbourhood, but rather to friends who lived in the local town or from school. One respondent reflected on the fact that these online relationships probably weakened rather than strengthened social bonds in the locality. For older people too, much of the time online is spent communicating with personal networks outside of the community, for example through "Friends Reunited". Even neighbours were more likely to communicate by email.

It is indicative of the Commuter Village that privacy within community was stressed:

The ideal community for me is a safe community, where you know people are looking after one another, but it's not intrusive. So, if for example, if somebody wanted to organise street parties or force events, I wouldn't enjoy that. Because I'd feel like I wasn't participating and I'd feel like I should, and then I'd feel guilty and all that stuff. So I would like a caring community that understands people need their individual spaces. (Male, CV)

In terms of bonding social capital, one part of Peninsula Village consisted of a dense network of family ties among the longer term residents going back a number of generations to the fishing community. However, incomers have also become relatively well established connected by friendship links and shared enterprises such as the film festival and the New Year dip. Their ties were often based upon bringing up children in the community using common childcare facilities.

By contrast, most residents of Commuter Village were relatively recent arrivals and from highly mobile professions, so they maintained their networks outside and beyond the village. One of the factors attracting them to the area was the fast broadband services, which they also commented approvingly, had led to a rise in house prices. These services enabled them to better connect with friends, relatives and work colleagues in remote locations. Since those working in the oil industry are often working at remote locations around the world, this opportunity for global networking was seen as a great advantage. Moreover, Facebook and email provided a way for people who knew each other only passingly to get together and arrange barbeques and other private social activities.

We've all found each other on Facebook, we all started talking to each other on Facebook. And we've been invited to barbeques, so the network of people you know grows... it's a diverse population, from all sorts of different backgrounds. And they're very sociable and alcohol seems to bond them together. It seems to be partying type of thing.. and there's a big field at the back of CV, so it is kind of used like a social area. (Male CV)

Therefore, both in Commuter Village and in Peninsula Village, social networks were important and were facilitated through ICT communications. However, in Peninsula Village these were focused more on the location, whilst in Commuter Village, they tended to link to various personal communities that were unlikely to be linked to the Village. Social groups within each village - for example, young people, tended to use information in different ways to other generations; the role of ICT was differentially incorporated in their day-to-day lives.

\section{Social integration: a sense of belonging}


Another aspect of social integration was the creation of a sense of belonging or identification with the place. Both communities evinced a sense of belonging to the community. However, whilst in Peninsula Village this tended to manifest itself as a commitment to the community itself,

There's lots of projects in Peninsula Village, it's a very good close-knit village there where when anyone does something, they do try and get that mix of everyone being invited along, and I guess when you're also in these committees you're in the know-how. We're doing another project, Peninsula Homes and Heritage, and we started that, and that is about we'll go along on Thursday, we'll scribe about working with the Older People's Club, they need 60 to 100, and we're very closely - I mean I'm really fond of the older people in our community, and very fond of them to see the young people in a positive light. So we will be doing some scribing and we will be listening to memories about some of the houses and the young people will receive these memories, and there's a number of events that will happen which will be a lot of intergenerational work. ........ we'll have young people educating older people in the community on how to use your mobile phone, how to use computers, so we do do a lot of work with different ages. (Female PV)

In Commuter Village respondents stressed rather the value of the landscape and the local amenities rather than the sense of community.

I mean unfortunately there's no services in the village really in terms of shops or anything, or post-office and stuff, which is a shame. There used to be a post-office and a shop. There was the pub, the Boar's Head, which was great. I could walk there from my house. Now that's gone to a Boar's Head Indian Restaurant, so not ideal, but still has a bar, so that's ok. So Commuter Village is not really the draw for us, I mean the draw is the rural environment that we live in, so I mean that's just fabulous. And I just love it, you know, we stand in the middle of the countryside really, surrounded by barley fields and pastures and forests and stuff (Male, CV).

However, exploring a community online was seen as a relevant way to get to know a place prior to moving there. As one respondent said "So once I started thinking of Commuter Village as a home, I started to look at the website a little" (Male CV). For people in Commuter Village, using broadband enabled them to work from home and advantages such as shopping or watching films were stressed as well as skyping with friends and relatives. For some it was a way of developing self employed enterprises and consultancies.

The role of community heritage provided a sense of connectedness which all could share in Peninsula Village, but this sense of historical cultural heritage had not been developed in Commuter Village. Cultural heritage can be an important way in which place identities are constructed and this is increasingly centred around online or digital resources (Tait, et al., 2013; Tait, et al., 2011). Community heritage activities were visible in Peninsula Village but not in Commuter Village. In Peninsula Village, a much frequented website was one devoted to historical heritage, where pictures and stories from the past were posted and shared. Community heritage brought together the different elements of village life providing information, photos and oral history testimonies both online and in exhibitions in the community as a place, thus contributing also to system integration. An active local history society met once a month and on the occasion we attended, it hosted some forty people. A number of historical buildings have been restored through fund raising around this topic and these are staffed by volunteers on the days they are open or converted to community use. 
One is a hostel with performance space and another is an art gallery and studio. Local historians have contributed books and other publications to this endeavour and there are commemoration plaques to significant historical figures on some of the well restored and preserved historical buildings. Those in Commuter Village valued the peaceful rural landscape and the value of their own houses but did not connect this to a sense of history of the place, perhaps because their own connection to it was relatively recent and a sense of history was not encouraged by their professional lives.

A sense of belonging was also fostered by communal events in Peninsula Village. These included the New Year dip which involved running into the sea at New Year - something in which many people joined in and it was commemorated by a film on the Community website. Other communal activities involved performance of an opera written by a local composer and performed by the children of Peninsula Village, again commemorated on a public broadcast and a CD. Finally the Film Festival was organised by the local film society to bring films and directors to the area during the winter. None of these things existed in Commuter Village, where the local towns probably provided enough cultural events for those who were interested.

Therefore there were different orientations to the past and a different sense of identitification with place in the two villages.

\section{Social integration: The common good}

Social integration is expressed through a commitment to the "common good". Many people in Peninsula Village had a lot of commitment to the common good and worked as volunteers in various community activities such as the local museums (there were three of them) or with various community associations. There were a great many such associations, such as an old persons club, linked to the community and a number of social enterprises - for example a local café and a proposed retirement home - so that doing something for the community was seen as a common practice.

In Commuter Village, by contrast, there was some difficulty in getting people involved in community life and the social entrepreneur who set up the broadband relayed this experience:

You know, I've experience a lot of anti community spirit here. For example, I was asking a farmer whether I could put a relay site (for the community broadband), a very small relay site, on the side of a disused barn. And he said "Oy, don't put any rubbish on the side of my barn!" and I said "but it's a community project" and he said "I don't care about that. Why should I care about CV or any other community?" And he just closed the door in my face. Well, you know, I had quite a lot of that at the beginning. (Male CV)

In Peninsula Village there was much more obvious dedication to common projects. An example would be the Cheese Shop initiating a community arts event whereby there was an "open house" and people can go from house to house enjoying artistic experiences such as joining in with music. Other events such as a film festival and crime writers weekends were organised for those both inside and outside the community. However, the work of organising these events is spread across a number of people and organisations, whilst in Commuter Village it was acknowledged that the kinds of community enterprise that took place depended upon the initiative of just one or two people and 
could collapse if these people were no longer able to do them. A festival in the field behind the village was organised intermittently depending upon the time and willingness of another local resident, who started this as a celebration of his fortieth birthday, but this was also mainly a private event. Hence the way in which community organisation works differs markedly in the two localities and this tends to be reflected in the online communications.

A commitment to the common good is an important element of the social integrational aspects of social cohesion. This took different forms in the different localities and the more isolated nature of Peninsula Village perhaps encouraged volunteering and subscription to local events in that location. However, the influx of a bohemian creative class bringing idealism in terms of community relations and a commitment to making them work facilitated this sense of strong moral commitment. People in Commuter Village, by contrast, were more interested in having a peaceful life untroubled by demands and pressures from the local community but providing them with privacy and time to pursue their own interests. Online communications enabled and helped to recruit people to community activities in Peninsula Village, whilst these were lacking in Commuter Village.

\section{Conclusions}

We can see that social cohesion was manifested in very different ways in the two communities in question. Despite being of similar size and composition, the social relationships were very different. In Peninsula Village the commitment of the local creative class (which we have termed "bohemian") to developing a sense of solidarity was manifested in numerous organisations and voluntary activities. In Commuter Village, the more privatised lifestyles and identification with activities in nearby cities and towns rather than with the village meant that it was difficult to raise enthusiasm for a social enterprise and residents led more private lives from their own homes. Nevertheless online communications were important for residents to pursue their personal and professional lives and were also used to contact neighbours through a process of local re-embedding of social relationships.

ICT was used in Peninsula Village to bridge social divisions and self-consciously create an online cohesive community presence. In Commuter Village, the use of ICT tended to reflect private networks and preoccupations, even when these were locally based (for example getting together for a barbeque). The layering of communities through changing populations, cultural and generational divides meant that some people connected more to the place in which they lived, using ICT to reembed their social relationships, whilst for others this was a way of connecting to outside or preexisting networks, which might even have undermined local social cohesion. Hence, we can say that ICT might in some ways have encouraged local social cohesion, but in other ways undermined it, depending upon how it is used. We have tended to focus upon the former in this article because it was the focus of our interest, but was should bear in mind that because much of the ICT communication was public, it was a way of connecting the community to the outside world rather than being inwardly focused. Here we have focused upon publicly accessible ICT for our analysis, which is necessarily only part of the picture.

The study of the two Scottish rural communities illustrates the fact that social cohesion can be built with the help of ICT given the right circumstances. The creation of system integration can be associated with offline meeting places, but also online sites that connect different interests and cultural groups. It can help to foster a sense of social integration through social networks (both 
bridging and bonding), through enabling a sense of identity, for example through communal events or interest in historical heritage and it can encourage commitment to the common good by creating new opportunities for volunteering and participating in local activities. Although we developed these theoretically derived analytical categories for analysis of complex interrelations between online and offline communications, in practice they tended to overlap one another. For example, the communal website in Peninsula Village was a also a vehicle for creating a sense of identity and enabling commitment to the common good, whilst in Commuter Village the communal spaces encouraged more private email and Facebook networks. Therefore these analytical categories of social and system integration were a good starting point for the analysis, but in practice quite difficult to disentangle..

Indeed we could argue that there is an important methodological advantage for studying communities using online presence in the way that we have, over more traditional methods. The online presence shows how communities represent and imagine themselves in ways that are unelicited. Furthermore, the detailed research of social media and other online sites can help to reveal the idea of "place" in social, cultural and economic relationships as different community interests (business, service, civil society etc.) represent themselves in different media and in different ways.

In this community-building enterprise, ICT can play an important part. ICT enables various elements of the community to connect to one another and the community to present itself to the world, ensuring both system integration at the level of the community and social integration in the way individuals were embedded in it. However, the way in which ICT is shaped depends upon the characteristics of the different residents and how their social relations have evolved. We are not arguing here for causality - ICT does not create social cohesion nor vice versa. Rather we are seeking to show how information and communications technology is intertwined with social life in rural communities in ways that co-evolve. It might be objected that we should take an unconnected community to provide a true counterfactual contrast for the use of community ICT. However, apart from the difficulties of finding a community that is not touched by digital communications, this would be unable to capture the multiplicity of community communications and how these takes place. Whilst we are not arguing that these communities are typical, they do represent contrasting forms of rural life in the contemporary British countryside.

In this process there is a re-embedding of social relationships using various community initiatives online as well as offline so that a sense of community can be developed. In one community (Peninsula Village) this took the form of developing local social cohesion and bridging community cleavages through multiple and diverse forms of communication both online and offline. In Commuter Village, whilst digital communications were also important to residents, they tended to reinforce separation between residents, so that locality based communications were far more limited. Therefore, although ICT can help to promote social cohesion, this needs to be seen in terms of the structure and development of the community as such. 


\section{References}

Abbott, P. and Wallace, C., (2012). 'Social Quality: A way to measure the quality of society'. Social Indicators Research, 108 (1):153-167.

Abbott, P., Wallace, C. and Sapsford, R., (2016). The Decent Society. London and New York:

Routledge.

Anderson, B., (1983). Imagined Communities. Reflections on the origin and spread of nationalism. London: Verso.

Berger Schmitt, R., (2002). 'Considering social cohesion in quality of life assessments: concept and measurement'. Social Indicators Research, 58:403-428.

Bosworth, G. and Willett, J., (2011). 'Embeddedness or Escapism? Rural Perceptions and Economic Development in Cornwall and Northumberland'. Sociologica Ruralis, 51 (2):195-214.

Bourdieu, P., (1983). 'Forms of Capital'. In: Richardson, J. (ed). Handbook of Theory and Research in the Sociology of Education. New York: Greenwood Press.

Bourdieu, P., (1984). Distinction. London: Routledge \& Kegan Paul.

Calhoun, C., (1998). 'Community without Propinquity Revisited: Communications Technology and the Transformation of the Urban Public Sphere'. Sociological Inquiry, 68 (3):373-397.

Champion, T. (ed), (1989). Counterurbanisation: the changing pace and nature of population deconcentration. Sevenoaks: Edward Arnold.

Crow, G., (2002). Social Solidarities. Theories, Identities and Social Change. Buckingham, Philidelphia: Open University Pres.

Dragolov, G., Ignacz, Z., Lorenz, J., Delhey, J. and Boehnke, K., (2013). Social Cohesion Radar.

Measuring common ground. An international comparison of social cohesion. Gutersloh: Bertelsmann Stiftung.

Durkheim, E., (1964). The Division of Labour in Society. New York: Free Press.

Dutton, W., H. and Blank, G., (2012). Next Generation Users: the Internet in Britain. Oxford Internet Survey Report. Oxford: Oxford Internet Institute.

Ellison, M. (ed), (2012). Reinventing Social Solidarity across Europe. Bristol, Chicago: Policy Press.

Florida, R., (2002). The Rise of the Creative Class: and How It's Transforming Work, Leisure,

Community and Everyday Life. New York: Basic Books.

Giddens, A., (1991). Modernity and Self-Identity. Cambridge: Polity Press.

Granovetter, M., (1974). Getting a Job: a study of contacts and careers. Cambridge, Mass.: Harvard University Press.

Guibernau, M., (2013). Belonging. Solidarity and Division in Modern Societies. Cambridge: Polity. Halfacree, K., H., (2008). 'To revitalise counterurbanisation research? Recognising the international and fuller picture'. Population, Space and Place, 14:479-495.

Huysman, M. and Wulf, V. (eds), (2004). Social capital and information technology. London, Cambridge Mass.: MIT Pres.

Ingold, T., (2000). The Perception of the Environment. London and New York: Routledge.

Jedrej, C. and Nuttall, M., (1996). White Settlers. The Impact of Rural Repopulation in Scotland.

London and New York: Routledge.

Jones, H., (2013). Negotiating Cohesion, Inequality and Change. Uncomfortable positions in Local Government. Bristol and Chicago: Policy Press.

Larsen, C.A., (2013). The Rise and Fall of Social Cohesion. The construction and deconstruction of social trust in US, UK, Sweden and Denmark. Oxford: Oxford University Press.

Lin, N., (2001). 'Building a network theory of social capital'. In: Lin, N., Cook, K. and Burt, R., S. (eds). Social Capital. Theory and Research. New York: Walter de Gruyter.

Lin, N., Cook, K. and Burt, R., S. (eds), (2001). Social Capital. Theory and Research. New York: Walter de Gruyter.

OECD, (2008). OECD Rural Policy Reviews: Scotland, UK. Paris: OECD. 
Pahl, R.E. and Spencer, L., (2004). 'Personal Communities. Not simply families of fate or choice'. Current Sociology, 52 (2):199-222.

Phillips, D., (2006). Quality of Life. Concept, Policy, Practice. London and New York: Routledge.

Pigg, K., E. and Crank, L., D. , (2005). 'Do information technologies promote rural economic development?'. Community Development, 36 (1):65-76.

Putnam, R., D., (2000). Bowling Alone. The Collapse and Revival of American Community. New York: Simon and Schuster.

Putnam, R.D., Leonardi, R. and Raffaella, N., (1993). Making Democracy Work. Civic Traditions in Modern Italy. Princeton, N.J. : University of Princeton Press.

Rainie, L. and Wellman, B., (2012). Networked. The New Social Operating System. Massechusetts: MIT Press.

Savage, M., (2010). Identities and Social Change in Britain since 1940. The Politics of Method. Oxford: Oxford University Press.

Spencer, L. and Ritchie, J., (1994). 'Qualitative analysis for applied policy research'. In: Bryman, A. and Burgess, R.G. (eds). Analysing Qualitative Data London and New York: Routledge.

Stockdale, A., Philip, L. and MacLeod, M., (2013). 'Retirement Transition Migration: Impllications for Rural Development'. Journal of Rural and Community Development, 8 (3):303-320.

Tait, E., MacLeod, M., Beel, D., E., Wallace, C., D. and Mellish, C., S., (2013). 'Linking to the Past: An Analysis of Community Digital Heritage Initiatives'. Aslib Proceedings, 65 (6).

Tait, E.J., Wallace, C., Mellish, C.S., McLeod, M. and Hunter, C.J., (2011). 'Creating and sustaining rural digital heritage resources using online databases'. Supporting Digital Humanities. Answering the Unaskable. Copenhagen, Denmark.

Townsend, L., Sathiaseelan, A., Fairhurst, G., Wallace, C. and Anderson, A.A., (2013). 'Enhanced broadband access as a solution for the social and economic problems of the rural digital divide'. Local Economy.

Townsend, L., Wallace, C. and Fairhurst, G., (2015). "Stuck out here': the critical role of broadband for remote rural places'. Scottish Geographical Journal.

Townsend, L., Wallace, C., Smart, A. and Norman, T., (2015 ). 'Building virtual bridges: how rural micro-enterprises develop social capital in online and face-to-face settings'. Sociologica Ruralis. Turkle, S., (2013). Alone Together: Why we expect more from technology and less from each other. Philadelphia: Basic Books.

Wallace, C., (2013). 'Is Social Quality enhanced by information technology and communications ? '. International Journal of Social Quality. 
